\title{
The European Union approach to flood risk management and improving societal resilience: lessons from the implementation of the Floods Directive in six European countries
}

\author{
Sally J. Priest ${ }^{1}$, Cathy Suykens ${ }^{2}$, Helena F.M.W. Van Rijswick ${ }^{2}$, Thomas Schellenberger ${ }^{3}$, Susana Goytia ${ }^{4}$, Zbigniew W. Kundzewicz $^{2}$ \\ ${ }^{5,6}, \underline{\text { Willemijn J. van Doorn-Hoekveld }}^{2}, \underline{\text { Jean-Christophe Bevers }}^{7}$ and $^{\text {Stephen Homewood }}{ }^{1}$
}

\begin{abstract}
Diversity in flood risk management approaches is often considered to be a strength. However, in some national settings, and especially for transboundary rivers, variability and incompatibility of approaches can reduce the effectiveness of flood risk management. Placed in the context of increasing flood risks, as well as the potential for flooding to undermine the European Union's sustainable development goals, a desire to increase societal resilience to flooding has prompted the introduction of a common European Framework. We provide a legal and policy analysis of the implementation of the Floods Directive (2007/60/EC) in six countries: Belgium (Flemish region), England, France, the Netherlands, Poland, and Sweden. Evaluation criteria from existing legal and policy literature frame the study of the Directive and its effect on enhancing or constraining societal resilience by using an adaptive governance approach. These criteria are initially used to analyze the key components of the EU approach, before providing insight of the implementation of the Directive at a national level. Similarities and differences in the legal translation of European goals into existing flood risk management are analyzed alongside their relative influence on policy and practice. The research highlights that the effect of the Floods Directive on increasing societal resilience has been nationally variable, in part because of its focus on procedural obligations, rather than on more substantive requirements. Analysis shows that despite a focus on transboundary river basin management, existing traditions of flood risk management have overridden objectives to harmonize flood risk management in some cases. The Directive could be strengthened by requiring more stringent cooperation and providing the competent authorities in international river basin districts with more power. Despite some shortcomings in directly affecting flood risk outcomes, the Directive has positively stimulated discussion and flood risk management planning in countries that were perhaps lagging behind.
\end{abstract}

Key Words: adaptive governance; Floods Directive; legal analysis; policy analysis; societal resilience

\section{INTRODUCTION}

Flooding in Europe is worsening, with increasing damages and rising pressure on disaster risk financing (EC 2004, Jongman et al. 2014). It is clear that not all flood risks can be avoided, and flood risk management (FRM) and its effectiveness between countries is highly variable (Alexander et al. 2016, Ek et al. 2016, Kaufmann et al. 2016, Larrue et al. 2016, Matczak et al. 2016, Mees et al. 2016). Some countries have a well-established and long-held approach to managing flood risk, whereas others lag behind. Differences in flood management are not inherently problematic; countries have developed flood risk policies in an autonomous way, permitting the tailoring of responses to local flood risk situations (including flooding type, severity, and extent) as well as recognizing the political priorities and existing legal context. The European Commission, however, has recognized that disparate and ineffective flood risk management, particularly in the transboundary context, has the ability to undermine the European Union's long-term goals for sustainable development, taking into account the effects of flood events on the economy, the environment, and human health (EC 2004). The lack of a coherent legislative and policy action at the EU level was considered to be undermining the ability to manage flooding effectively, now and in the future. It has emphasized the need for a common framework for better managing floods across borders, thereby improving transboundary cooperation and coordination, particularly between upstream and downstream communities. Here, we analyze whether adopting a common European approach to FRM is able to deliver enhanced societal resilience in transboundary river basins and in those countries where it is implemented.

The European Commission introduced Directive 2007/60/EC on the assessment and management of flood risks (the Floods Directive, henceforth referred to as the FD; EC 2007) with the aim of encouraging a minimum common framework to managing flooding and to reduce impacts on European societies. The FD states that floods have the potential to cause fatalities, displacement of people, and damage to the environment, and to compromise severely economic development and activities. Although the FD recognizes that floods are unpreventable natural phenomena, better management of societal activities (e.g., preventing increasing economic development and human settlement on floodplains) is feasible and desirable to reduce the risk of adverse consequences. However, the FD's use of procedural obligations rather than substantive requirements raises questions concerning its ability to meet these aims and deliver more resilient FRM (Keessen and van Rijswick 2012).

There is an existing body of research with a combined policy-legal perspective of resilience and adaptive water management. Each of the following examples focuses on different aspects of socialecological resilience: general perspectives (Ebbesson 2010); integrated water management and adaptation to climate change (Keessen and van Rijswick 2012); and specific elements that may improve resilience such as flexibility (Green et al. 2013), legitimacy

${ }^{1}$ Flood Hazard Research Centre, Middlesex University, UK, ${ }^{2}$ Utrecht Centre for Water, Oceans and Sustainability Law, Utrecht University, The Netherlands, ${ }^{3}$ University François Rabelais, France, ${ }^{4}$ Luleå University of Technology, Sweden, ${ }^{5}$ Institute of Agriculture and Forest Environment, Polish Academy of Sciences, Poland, ${ }^{6}$ Potsdam Institute for Climate Impact Research, Germany, ${ }^{7}$ Institute for Environmental and Energy Law, KU Leuven, Belgium 
and public participation (van Buuren et al. 2014), or the ability to learn and change existing policies (Tennekes et al. 2014). We draw on varied examples of FRM in selected European Union countries: Belgium (Flemish Region), England, France, the Netherlands, Poland, and Sweden. A dual policy-legal perspective allows the assessment of the contribution (and further potential) of the FD and its national implementation to increase social resilience by using an adaptive governance approach. We focus on the following research questions:

1. What is the aim of an EU flood risk policy and how has it been designed to fit with the EU's legal framework?

2. How has the FD been implemented and integrated into the legal and existing FRM approaches within each country? What changes in FRM have resulted?

3. To what extent has the FD been able to promote adaptive governance and enhanced societal flood resilience? What recommendations can be made to improve this resilience at national and EU levels?

\section{METHODS}

We present findings from the EU-funded STAR-FLOOD project, which focused on analyzing, explaining, and evaluating flood risk governance in Europe. A comparative legal approach (Reimann and Zimmermann 2008, Bell et al. 2013) has been complemented by policy analysis to provide a comprehensive examination of the extent to which changes to FRM resulting from the FD is enhancing flood resilience. Extensive desk-based policy and legal analysis of legislation, policy documentation, and draft flood risk management plans (FRMPs) has been used to analyze how the FD has been implemented in each of the six study countries, as well as provide insight into how it is performing. This was complemented by semistructured interviews conducted with a range of professional stakeholders involved in flood risk policy development and local implementation such as flood and water managers, spatial planners, emergency planners, and insurers. These interviews have provided invaluable insight about how the FD has been integrated into national policies and operationalized, providing lessons on its effects on societal resilience to flooding. Furthermore, specific transboundary examples are used to highlight good or poor cases of implementation and to reflect on how the FD is considered in practice. The selected comparative countries represent situations with varying flood risks, forms of state organization (centralized, federal, decentralized), legal systems, geographical location (North, East, West and central Europe), and existing approaches and traditions of FRM. The countries therefore vary in terms of the effects the FD has had on national policies and legal frameworks. This variation enables findings and lessons to be drawn that may be more broadly relevant within the EU and internationally.

\section{FLOOD RESILIENCE: THE ROLE OF ADAPTIVE GOVERNANCE IN IMPLEMENTATION OF THE FLOODS DIRECTIVE}

The principle of resilience itself does not explicitly occur in EU Treaties or secondary legislation such as the FD but is considered more implicitly in the EU approach. Resilience is a welladdressed, although contested, topic in relation to the management of environmental risks (e.g., Gunderson and
Holling 2002, Folke et al. 2005, Huitema et al. 2009, Garmestani and Benson 2013, Chaffin et al. 2014). Our research encompasses broad and complex notions of resilience that couple social and ecological systems (Folke 2006, Young et al. 2006). Combining notions from both the legal and policy literature, resilience is herein defined as being a measure of the ability of a system to undergo a disturbance without experiencing a fundamental change to its structure, status, or processes (Cosens 2010, Keessen and van Rijswick 2012).

Flooding is inherently dynamic. Therefore, learning is a critical component of flood resilience to encourage change, adaptation, and system transformation (Carpenter et al. 2001, Walker et al. 2004). Adaptation and adaptive capacity have emerged as key linked concepts for resilience and are particularly relevant to FRM, in which the role is to manage current and uncertain future risks (Cosens and Williams 2012, Chaffin et al. 2014). Furthermore, in the context of climate change, adaptive FRM is seen as essential to ensure the continued safety of citizens and mitigate the adverse effects on the economy, health, environment, and cultural heritage (EC 2009, recital 4 FD). Consequently, there is a need to consider approaches to managing flood risk that balance addressing the short-term consequences of flooding with the ability to change and react to deliver sustainable futures (Folke 2006).

Meeting these multiple requirements demands FRM approaches based on forms of adaptive governance (Folke et al. 2005). Adaptive governance recognizes and incorporates the need to manage complexity and uncertainty (Dietz et al. 2003) as well as the need to manage multiple scales and the cooperation of numerous institutions (Chaffin et al. 2014). The principle of subsidiarity, inherent within much EU legislation, is a concept that acknowledges that effective management requires consideration of the scale at which it is implemented. Indeed, Green et al. (2013) highlight that the nested approaches to governance advocated by some EU Directives (such as the Water Framework Directive [WFD]), which include managing risks at multiple scales, are symptomatic of managing the inherent complexity of changing and uncertain systems. The river basin approach, not only with respect to river basin districts shared between states, but also at the more local level, is thus an important element for evaluating resilience of flood risk policies and is one of the aspects analyzed here.

The existing international research literature reveals a number of characteristics indicative of adaptive governance (e.g., Folke et al. 2005, Chaffin et al. 2014; Table 1) that can be used as an evaluative framework to assess EU flood policies and instruments. This literature includes both theoretical and empirical approaches to considering adaptive governance and provides a foundation for investigating the FD and its implementation. Our evaluation further builds on that of Keessen and van Rijswick (2012), who state that promoting resilience through the legal system requires finding a mode of rendering adaptive governance elements compatible with the requirements of the rule of law (Ebbesson 2010). Additionally, Wiering et al. (2015) highlight the importance of considering existing governance approaches when evaluating whether a system is ultimately resilient, including prevailing social relations and political and social arguments about FRM. As such, from a policy implementation perspective, the FD and its policies 
Table 1. Evaluation criteria to assess the resilience of European Union and national flood risk management policies.

\begin{tabular}{|c|c|c|}
\hline Evaluation criterion & Explanation & Relevant literature $^{\dagger}$ \\
\hline $\begin{array}{l}\text { Multilevel governance at } \\
\text { the bioregional scale }\end{array}$ & $\begin{array}{l}\text { The river basin approach is one of the cornerstones of the Water } \\
\text { Framework Directive and Floods Directive and should thus be } \\
\text { reflected in flood risk management policies. Most river systems } \\
\text { operate over a range of spatial scales and institutional levels (Cosens } \\
\text { et al. 2014). This is especially the case in relation to transboundary } \\
\text { river systems, necessitating multilevel governance }\end{array}$ & $\begin{array}{c}\text { Folke et al. }(2005)^{\mathrm{T}} \text {, Olsson et al. }(2006)^{\mathrm{E}}, \text { Huitema } \\
\text { et al. }(2009)^{\mathrm{T}}, \text { Cosens }(2010)^{\mathrm{E}}, \text { Keessen and van } \\
\text { Rijswick }(2012)^{\mathrm{T}, \mathrm{E}}\end{array}$ \\
\hline Adaptability & $\begin{array}{l}\text { Improving the adaptability of rules to enable learning. This refers to } \\
\text { using assessments and monitoring results in an iterative process of } \\
\text { decision making }\end{array}$ & 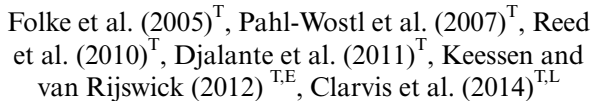 \\
\hline $\begin{array}{l}\text { Effective public } \\
\text { participation and access } \\
\text { to justice }\end{array}$ & $\begin{array}{l}\text { Openness and participation in decision making and access to justice } \\
\text { to enable goals to be achieved in a legitimate way. Citizens should be } \\
\text { engaged early in the process, there should be a process to embed } \\
\text { participatory outcomes, and there should be opportunity to challenge } \\
\text { decisions }\end{array}$ & $\begin{array}{c}\text { Huitema et al. (2009) }{ }^{\mathrm{T}} \text {, Keessen and van Rijswick } \\
(2012)^{\mathrm{T}, \mathrm{E}} \text {, Van Buuren et al. }(2014)^{\mathrm{E}, \mathrm{L}} \text {, Hartmann } \\
\text { and Spit }(2016)^{\mathrm{E}}\end{array}$ \\
\hline $\begin{array}{l}\text { Effectiveness in goal } \\
\text { attainment } t^{\star} \text { : follow-up } \\
\text { and enforcement }\end{array}$ & $\begin{array}{l}\text { The legal framework is adequate in enabling the achievement of its } \\
\text { aims. For this purpose, the legal framework should provide the } \\
\text { necessary conditions for implementation of the rules, which includes } \\
\text { their enforcement by public and private actors, and should not } \\
\text { provide obstacles that hinder implementation }\end{array}$ & $\begin{array}{l}\text { Dietz et al. }(2003)^{\mathrm{T}} \text {, Buijze }(2009)^{\mathrm{T}, \mathrm{L}}, \text { Green et al. } \\
(2013)^{\mathrm{T}, \mathrm{L}, \mathrm{L}}, \text { Söderasp }(2015)^{\mathrm{E}, \mathrm{L}}\end{array}$ \\
\hline Diversification & $\begin{array}{l}\text { Diversity of strategies (e.g., flood prevention, defense, mitigation, } \\
\text { preparedness, recovery) to manage flood risk in the national } \\
\text { implementing legal frameworks and policies, which should be made } \\
\text { possible by EU legislation }\end{array}$ & Folke $(2006)^{\mathrm{T}}$, Hegger et al. $(2014)^{\mathrm{E}}$ \\
\hline Goodness of fit & $\begin{array}{l}\text { Goodness of fit or misfit of the requirements of the Floods Directive } \\
\text { with existing national flood risk management approaches and rules. } \\
\text { Reflecting the EU principle of subsidiarity, this includes whether the } \\
\text { (new) Floods Directive instruments complement or conflict with } \\
\text { existing flood risk management at all levels of implementation }\end{array}$ & Wiering et al. (2014) $)^{\mathrm{E}}$, van Eerd et al. $(2015)^{\mathrm{T}, \mathrm{E}}$ \\
\hline
\end{tabular}

${ }^{\top}$ Superscrips indicate whether the paper was principally theoretically based (T), empirically based (E), or based on legal analysis (L).

${ }^{*}$ A goal attainment view of effectiveness considers whether a management instrument is able to achieve what it set out to do.

cannot be considered in isolation of what has come before and must recognize the extent to which instruments fit (or do not fit) with existing rules and practices (van Eerd et al. 2015). Therefore, true to the multidisciplinary approach adopted here, six evaluative criteria have been identified from policy and legal literature and from international law (Table 1). These criteria are used to assess both the EU framework for FRM and its national implementation within the six countries.

\section{EUROPEAN UNION LEGAL FRAMEWORK FOR FLOOD RISK MANAGEMENT}

\section{Background: European Union approach to flooding}

The EU is a supranational organization with certain competences in water and FRM. The EU legal setting distinguishes between primary EU law, i.e., the Treaties that establish the EU and its functioning, and secondary EU law (e.g., Regulations, Directives, case law) by which the EU regulates more specific policy fields. Directives have binding objectives and have to be transposed into national laws. As such, Directives set forth goals that should be reached, but they do not prescribe the manner in which the goals should be achieved. The administration of EU law is primarily in the hands of each country because it does not offer a general legal basis for the harmonization of institutional and procedural administrative law (Jans et al. 2007, Keessen and van Rijswick 2012). The EU legislator explicitly chose the Directive as the legal instrument because institutional and procedural autonomy is important for FRM and permits a certain degree of policy freedom.
European Union Floods Directive and its aims

The FD is called one of the "daughter directives" of the EU WFD. The WFD's main concepts and approaches all reappear in the FD including: river basin approach, transboundary cooperation, coordination of water quality and quantity management, coordination with other policy fields (e.g., nature conservation, spatial planning), adaptive and cyclic planning approach, and important roles for monitoring and public participation (van Rijswick and Havekes 2012). However, the strength of the obligations in framework Directives varies considerably, thereby affecting legal effectiveness. This forms the analytical focus of our study: To what extent is the FD, in its legal form and manner of implementation, able to deliver increased flood resilience?

EU flood risk management considers flooding as a natural phenomenon that cannot be prevented entirely, although the impacts can be lessened. A main aim of the FD is therefore stated as managing and reducing the impacts of flooding on people (including health and life), the economy, cultural heritage, and the environment (art.1 FD). Additional aims are to provide a common framework for better managing transboundary flood risks and to address recognized failings of existing FRM (EC 2004). The diversity of approaches in FRM throughout the EU and the need for better cooperation and coordination, particularly between managing upstream and downstream flood risks, constituted important incentives for adopting the FD. The FD also affords the opportunity for better coordination of national FRM with EU policy on the protection of water (i.e., the WFD) and adoption of a holistic river basin management approach, as 
well as ensuring cost effectiveness of the EU's FRM investment (e.g., through Structural Funds, Cohesion Funds, and Solidarity Funds; EC 2006). Addressing each adaptive governance criterion in turn, the following discussion illustrates the degree to which the FD is enabling flood resilience. Building on and deepening the analysis of Keessen and van Rijswick (2012), we provide a brief evaluation of the FD at the EU level, particularly focusing on the effects of the FD at a transboundary level (i.e., the coordination of approaches between states). We then focus on examples of national implementation of the FD in six countries. These examples provide valuable lessons for future development of national FRM, back to the EU level and internationally.

\section{NATIONAL IMPLEMENTATION OF THE FLOODS DIRECTIVE IN BELGIUM (FLEMISH REGION), ENGLAND, FRANCE, THE NETHERLANDS, POLAND AND SWEDEN}

The European Commission publishes overviews of the status of FD implementation in EU Member States (e.g., EC 2015). All six of the countries examined have successfully completed the notification of transposition, and the competent authorities and management units (summarized in Table 2) completed the Preliminary Flood Risk Assessment stage and published flood hazard and risk maps (EC 2016). At the time of writing, all countries had drafted and consulted about their FRMPs, and official publication of the results had begun.

\section{IMPACT OF THE FLOODS DIRECTIVE}

\section{Multilevel governance on a bioregional scale}

European flood risk regulation has adopted a bioregional scale and takes a river-basin approach, recognizing the transboundary nature of flood risk. Countries are required to identify river basins and assign them to individual river basin districts (art.3 FD, art.3 WFD; Green et al. 2013), and each has to ensure appropriate administrative arrangements (e.g., designation of competent authorities). Importantly, the measure of appropriateness here requires consideration of the whole (international) river basin, rather than just the national level. The FD adopts a multilevel approach to goal setting and the measures included in the FRMPs. In this way, it allows discretion when developing flood risk policies to fit the national and regional context but, in the end, guarantee that the FD's aims are achieved (Herman 2010). For example, one of the cornerstones of the FD's coordination requirements states that FRMPs may not include measures that could lead to a significant increase in risk upstream or downstream in another country within the river basin (recital 13 FD). This is an externalization of the solidarity requirement (see recital 15 FD; Keessen et al. 2010).

Countries that share an international river basin district should work together to produce one single international FRMP; however, if an agreement is not reached, separate national plans may be issued (art.8 FD). Shared planning, risk assessment, and goal setting are important in international river basin districts. The lack of embedding proper instruments for cooperation and coordination into legal frameworks (e.g., adequately functioning joint bodies at the level of the international district), thereby exclusively basing cooperation and coordination requirements on obligations of best efforts, can undermine transboundary cooperation (van Rijswick et al. 2010, Suykens 2015). Another important element related to the implementation of both the FD and WFD is that a coordinated approach should be adopted. For example, river basin management plans and FRMPs should be integrated, or their timelines, e.g., for public participation, should at least be synchronized. Implementing regulation is established at the national, regional, and (sub)river basin levels, which shows the necessity of examining actual flood risk policies in the selected countries. At the EU level, a coordinated approach between the FD and the WFD is being promoted and facilitated, though not obliged. At the national level, some countries not only recognize the relationship between FRM and the protection and improvement of the status of waters as required by the WFD, but also implement this relationship in their national laws and policies.

In terms of national implementation, all of the countries studied demonstrate a clear link between the WFD and FD and encourage multilevel governance to be adopted at the same scale, i.e., that of the river basin district (see Table 3). They all have the same competent authority for at least some of the (sub)river basins. There appears to be consistency in the implementation scale of the plans, however, this does not necessarily mean that effectiveness will result. Firstly, the scale of FRM planning may differ from that of implementation, and effective adaptive governance is dependent on successful coordination of multilevel decision making, as well as effective information exchange between institutions (Folke et al. 2005, Cosens 2010). For instance, despite Sweden having a common institution (county administrative boards) involved in the implementation of both the WFD and FD, these can often be observed as two processes working in parallel rather than an integrated program of work. Furthermore, in Sweden, effective integration may also be hampered by the differing national state agencies overseeing each Directive: the Swedish Agency for Marine and Water Management in the case of the WFD, and the Swedish Civil Contingencies Agency for the FD.

Flanders provides an example in which the FD and WFD are integrated and efforts are made to reflect the river-basin scale in management. The requirements of the FD have been implemented by further building on the existing legal framework implementing the WFD (the Decree on Integrated Water Policy) and applying the same competent authority (Coordination Commission on Integrated Water Policy). Furthermore, integration was also pursued at the planning level, with the FRMPs being fully integrated into the second generation of river basin management plans. Administratively, this gives the advantage that various similar procedural steps for both plans (e.g., public consultation, data gathering) can be combined. There is also content-based integration, with the proposed measures being unified into one set to fulfill the goals of both Directives.

The Netherlands is another country where there is high integration within water management, with the same law, the Dutch Water Act, incorporating both the WFD and FD, and the presence of appropriate coordination mechanisms between national and regional levels. Dutch responsibilities, powers, and resources are all situated within one authority, except for the relationship between water management and both spatial planning and civil protection. This is regarded as an advantage when adopting integrated water management measures, but it may hamper coordination between different FRM approaches.

In some countries, there is a divergence between those legally responsible for fulfilling the requirements of the FD (mostly the 
Table 2. General overview of the implementation of the Floods Directive (FD) in selected countries.

\begin{tabular}{|c|c|}
\hline Country & $\begin{array}{l}\text { Implementing legal framework and } \\
\text { relation to the Water Framework Directive } \\
\text { (WFD) }\end{array}$ \\
\hline $\begin{array}{l}\text { Belgium } \\
\text { (Flanders) }\end{array}$ & $\begin{array}{l}\text { FD and WFD implemented in the same } \\
\text { legal framework: the Decree Integrated } \\
\text { Water Policy of } 2003 \text { (as amended) }\end{array}$ \\
\hline England & $\begin{array}{l}\text { Transposed via the Flood Risk } \\
\text { Regulations 2009, and some provisions } \\
\text { were added to within the Flood and Water } \\
\text { Management Act } 2010\end{array}$ \\
\hline France & $\begin{array}{l}\text { Transposed via National Commitment for } \\
\text { the Environment Act } 2010 \text { (also called } \\
\text { Grenelle } 2 \text { Act). To implement the } \\
\text { Directive fully, a new legal system for } \\
\text { flood risk management is being developed } \\
\text { based on three new strategic documents } \\
\text { applicable to three different territorial } \\
\text { levels: national, watershed, and local }\end{array}$ \\
\hline The & Transposed in Water Act and Water \\
\hline Netherlands & $\begin{array}{l}\text { Decree. Almost fully integrated water } \\
\text { management included in the Water Act, } \\
\text { which provides for integration of the } \\
\text { WFD and the FD. Urban flooding (from } \\
\text { sewers) is transposed in the Environmental } \\
\text { Management Act. Standards for pluvial } \\
\text { flooding are set by the provinces. } \\
\text { Emergency management is regulated in } \\
\text { the Security Regions Act, but has a far } \\
\text { broader scope than only water-related } \\
\text { risks }\end{array}$ \\
\hline
\end{tabular}

Poland Achieved in January 2011 (post-deadline) by passing regulations to change existing Water Law (Dz.U. 2011 No. 32 item. 159); subsequently undergone further revisions (latest December 2015)

Sweden FD and WFD implemented through different legal instruments. Different state agencies at national level with competence for each directive. Coordination requirements applicable.

\author{
FD competent authorities
}

River basin authority: competences and financial resources

Coordination Committee Integrated Water Policy for implementation of both the WFD and FD

Environment Agency (also for the

WFD); new Lead Local Flood

Authorities are competent authorities for some functions

Minister of Environment and Infrastructure (Rijkswaterstaat); water boards for regional waters; municipalities for urban water management

Several competent authorities for different flood risk management functions: e.g., National and Regional Water Management Boards (KZGW and RZGWs); Provincial Authorities of Drainage, Irrigation, and Infrastructure (WZMiUWs); and Fire Brigades. Eight of the 46 FD competent authorities are also WFD competent authorities Swedish Civil Contingencies Agency (Myndigheten för samhällsskydd och beredskap) has overall responsibility for implementation of the FD
Flemish basin boards are the relevant entities at the sub-basin scale; however, they lack independent financial resources and legal personality Environment Agency is responsible for managing river basin districts and producing flood risk

management plans (FRMPs; seven wholly within England and two cross-border). The Environment Agency and FRMPs are principally state funded; funds for other competencies may also be from locally generated taxes

FRMPs are adopted by the State at a bioregional scale (Prefect of the basin) after a draft made by the river basin committee. The river basin committee gathers several stakeholders in the field of water management, but the approval of FRMPs relies on the prefect of the basin. Funding is from the State

National: Minister of Environment and Infrastructure: regulation, FRMPs, implementation of measures, enforcement, formulation of transboundary agreements at state level, coordination, and supervision; financed by general taxes;

Regional: water boards: regulation, FRMPs, implementation of measures, and enforcement; flood risk management subriver-basin: financed by specific taxes that ensure sufficient financing; Municipality: urban water management; specific taxes;

Provinces: regulation (safety standards for secondary flood defenses, pluvial flooding), flood risk maps, coordination and supervision of water boards and municipalities

Not all relevant issues are tackled in hydrographic units; RZGWs are based on drainage basins, whereas WZMiUWs are based on administrative areas. KZGW and RZGWs are financed by the state. WZMiUWs receive funds from the ministries and apply for EU structural grants

County administrative boards (CABs; state agencies at regional level) involved in implementation of WFD and FD. The five CABs that were designated water authorities for WFD produced the FD's flood risk maps. Each of $\mathrm{CAB}$ where significant risk has been identified has produced a FRMP, which should be coordinated at the river basin district level. CABs are financed using state resources
State, but also some decentralized authorities), those who are preparing the information (often undertaken more locally), and those undertaking FRM in practice. Therefore, although the FD intends to provide tools that enhance resilience (e.g., a standardized and comprehensive approach to risk identification and FRM planning), the extent to which this is delivered in practice is limited because of the lack of possible implementation or enforcement. The situation in France highlights that although the transposition of the FD has established new strategic tools at different scales (e.g., a national-scale FRM strategy [Stratégie Nationale de Gestion des Risques d'Inondation], FRMPs, and local FRM strategies [Stratégie Locale de Gestion du Risque d'Inondation]) to complement the existing State-implemented Flood Risk Prevention Plan (Plan de Prévention du Risque d'Inondation), this has not been accompanied by sufficient devolution of power to enact change effectively. As such, power 
Table 3. Summary evaluation of the EU Floods Directive (FD).

\begin{tabular}{|c|c|}
\hline Evaluation criterion & Key findings for the EU level \\
\hline $\begin{array}{l}\text { Multilevel governance at the } \\
\text { bioregional scale }\end{array}$ & $\begin{array}{l}\text { FD adopts the river-basin scale as the unit of management and takes a multilevel approach to goal and standard } \\
\text { setting, which is a positive attibute for adaptive governance. However, the lack of proper instruments formally } \\
\text { embedded into the legal system may limit transboundary cooperation. Also, differences in the legal frameworks, } \\
\text { political viewpoints on flood risk management, and economic, social, and physical settings may hamper proper } \\
\text { coordination and cooperation between scales }\end{array}$ \\
\hline Adaptability & $\begin{array}{l}\text { Six-year cycle of plan review and update that requires the consideration of climate change; however, no } \\
\text { requirements about how learning should translate into management change. Much flexibility for Member States } \\
\text { to tailor management to local flood contexts, but the level of adaptability may hamper effectiveness in } \\
\text { transboundary environments }\end{array}$ \\
\hline $\begin{array}{l}\text { Effective public participation and } \\
\text { access to justice }\end{array}$ & $\begin{array}{l}\text { Public accessibility of maps and plans and inclusion of stakeholders in the production, review, and update of } \\
\text { flood risk management plans are included in the FD. However, the ability of citizens to challenge decisions and } \\
\text { enforce obligations is limited because of the design of and approach taken in the FD, which relies on national- } \\
\text { level rules for access to justice }\end{array}$ \\
\hline $\begin{array}{l}\text { Effectiveness in goal achievement: } \\
\text { follow-up and enforcement }\end{array}$ & $\begin{array}{l}\text { Despite the aims of delivering coordinated transboundary approaches, there is still variability across national } \\
\text { boundaries, which can be attributed to differences in: definitions of concepts; obligations and legal frameworks; } \\
\text { political viewpoints on flood risk management; and economic, social, and physical settings }\end{array}$ \\
\hline Goodness of fit & $\begin{array}{l}\text { Much flexibility within the FD for countries to select relevant risk levels and flood risk management objectives. } \\
\text { However, some requirements of the FD such as the development of flood risk management plans and the } \\
\text { introduction of participatory approaches will be more difficult and complex to implement if they are new and far } \\
\text { removed from existing approaches }\end{array}$ \\
\hline Diversification & $\begin{array}{l}\text { One of the stated aims of the FD is to promote a more diverse approach to managing floods. However, countries } \\
\text { are able to set their own objectives, and there are no fixed requirements to diversify the types of approaches used } \\
\text { to manage flooding }\end{array}$ \\
\hline
\end{tabular}

sharing in France is still considered to be weak. FRM remains largely state controlled, which has not significantly altered its traditional risk-oriented doctrine. Under these conditions, the FD has only a marginal effect on FRM policy, and thus, effectiveness will depend on how it is implemented in practice at the local level.

A similar situation can also be observed in Sweden, as the effectiveness of multilevel governance also links to implementation scales and issues of compliance. The FD was implemented through a Government Ordinance. Consequently, Swedish municipalities (FRM is largely undertaken at the local scale) have no formally imposed obligations in the implementation of the FD (Thorsteinsson and Larsson 2012, Hedelin 2016). As such, the state agencies with FD responsibilities have no possibility to ensure that municipalities adopt measures in accordance with the plans (MSB 2014). Therefore, there may be a gap between what is planned to fulfill the requirements of the Directive and how this translates to actual measures in practice. Despite this, for the most part, municipalities have been actively involved in the development of FRMPs, but outcomes are variable. For example, the measures in the FRMP for Kristianstad (Länsstyrelsen Skåne 2015) are limited to those to be undertaken by the county administrative board, whereas the FRMPs for Haparanda and Älvsbyn include annexes on "decided measures," i.e. measures that the county administrative board, the municipality, or another actor has committed itself to implement (Johansson 2015a,b).

\section{Adaptability}

The FD allows for two recognized components of adaptability: collection of up-to-date information for decision making, and rules that permit and encourage change based on this information (Keessen and van Rijswick 2012, Beijen et al. 2014). Similar to the WFD, the FD requires authorities to submit to a six-year cycle of planning and update, which includes any new data and thus encourages learning. The consideration of climate change and its effects on future risks provides a key justification for the creation of the Directive (recital 4, FD). Clarvis et al. (2014) identify a number of actionable legal mechanisms that facilitate and encourage change, including time-limited licensing, emergency provisions and powers, and monitoring standards (see also Goytia et al. 2016). Importantly, however, these are not required by the FD, but might be used locally or nationally to promote more adaptive FRM.

In practice, in all six countries, the FD has reinforced the need to consider future risks such as climate change and urbanization within the preliminary risk assessment (art.4(2) FD), and all have integrated climate change, to more or less degrees, within the riskmapping processes (EC 2016), despite it not being strictly necessary to do so. Moreover, the likely impacts of climate change are a fundamental requirement as part of the review process, and therefore, future concerns are embedded (art.14(4) FD). In Poland, the FD has imposed a systematic consideration of flood risk, an improvement on the ad hoc approach that dominated previously. Prior to the FD, FRM was not really open in public debate and was driven by a responsive mode after major inundations. Following floods in 1997, for example, rather than focusing on the improvement of FRM, it was the decision-making process that was criticized, and FRM failings were blamed on political shortcomings. This approach did not lead to a significant and coordinated strategy for increasing flood resilience. The FD has acted as a stimulus for FRM to be considered in a much more proactive and holistic way, and meeting the necessary requirements (e.g., preliminary flood risk assessment, production of flood hazard and flood damage maps and FRMPs) has been, in the Polish context, a considerable achievement.

However, the actual management of flooding and future risks is related to the quality of the FRMP and the prioritization of 
measures. In some countries (England, Flanders, and the Netherlands), learning was already well institutionalized within existing FRM policy and practice, although it has been strengthened by the FD and other ongoing activities (e.g., adoption of the risk-based approach and development of a Delta Program in the Netherlands; the reform of the Flemish Decree Integrated Water Policy in 2013 to integrate more flexibility in planning). In other countries, the FD has had a greater effect on encouraging adaptability. In Sweden, the iterative process required by the FD's implementation promotes knowledge generation about flood risks and their management. However, in practice, the provisions in the FD are somewhat limited. The only strict requirements relate to the six-year update cycle; any more comprehensive intermediate changes or continuous monitoring of the effectiveness of specific flood measures are at the discretion of national authorities.

Related to adaptability is flexibility and whether the FD's design permits sufficient scope for its goals to be achieved. Despite desiring a common FRM framework, the varying nature of flood risk geographically in Europe necessitates an approach that is not so prescriptive that it would prove unworkable or ineffective for some flood risks. Setting common European standards for flood protection was thus considered technically and politically infeasible (EC 2006). As such, the FD illustrates two key principles in EU law, proportionality and subsidiarity, and sets out procedures (e.g., creating flood risk maps and FRMPs), rather than outcome-based obligations. Countries have the discretion to set variable "appropriate objectives" to reach the overall aim of reducing adverse flood impacts (art.7(2) FD) and to update measures during the six-year update cycle (annex B $(3,4)$ FD). The focus of the FD encourages the consideration of countries' perspectives about what are considered appropriate levels of risk in the national and regional contexts, and what action should be taken to mitigate these risks. This may be problematic for transboundary FRM because there are no requirements that ensure, for instance, that risk assessments, standards, or objectives are coordinated. Furthermore, transboundary management may be hampered by variability in the competent authorities, afforded by the flexibility of the FD, which may have different responsibilities, roles, and legal status (van Rijswick et al. 2010, Suykens 2015). Generally, when the requirements of a European Directive are very strict, the Directive offers exemptions for not meeting the obligations (van Kempen 2012). It is therefore striking that the FD is so open and flexible that it does not include exemptions to be invoked for not being able to reduce potential adverse consequences of flooding (Howarth 2007, Herman 2010).

\section{Effective public participation and access to justice}

Following adherence to the Aarhus Convention, EU water management is guided by public participation and mandatory disclosure provisions to improve decision making and legitimacy (EC 2003, Directive 2003/35, EC Regulation 1367/2006). The FD promotes disclosure and transparency because it requires that flood risk maps and plans are publicly accessible and additionally that "interested parties" are involved in the "production, review, and updating of plans" (art.10 FD). Although the FD provides for the involvement of stakeholders, and in particular, citizens, within FRM planning, the effect is questionable. National implementation of participation is variable and relates closely to the extent to which countries were already engaged in efforts to include stakeholders within decision making because there is a lack of specific requirements in the FD about what participation should include. Greater efforts could be made to coordinate and integrate public participation related to the FD with that of the WFD (art. 9.3 FD), although these efforts may be better facilitated by the synchronization of the planning timescales of the Directive after the initial FRMPs in 2015.

There is a great deal of variability in national implementation of the public participation requirements; some countries have seen little change because flood risk disclosure and public participation were already well developed and institutionalized. England, for instance, already undertook a high degree of participation with a wide variety of stakeholders prior to implementation. Recent years have seen the formalization of some aspects and the introduction of additional consultees, although this is not only as a direct result of the FD, but is also linked to perceived gaps in communication or failings from previous events (e.g., Pitt 2008). In the Netherlands, access to information and public participation was also well institutionalized and increasing in importance (OECD 2014). It has not been changed purely as a result of the $\mathrm{FD}$, and there is general a lack of citizen interest in participating because of low flood awareness and a perception that most areas are already protected (Kaufmann et al. 2016). France has complied with the minimum requirements of information availability (art.10 FD), and citizens have been consulted. However, in contrast to other countries such as England and Sweden (see MSB 2014, Environment Agency 2015), there has been no reporting about how public (and other stakeholder) comments have (or have not) been taken into account. Similarly, although Flanders has a well-institutionalized approach, it is not clear how consultation information will be used.

In contrast, in Poland, the FD is observed as having a much greater resilience-enhancing effect through public participation. The importance of participation has increased markedly since implementation, and enhanced public consultations are recognized as effecting awareness raising and social learning. Flood risk is now present in the public discourse, even if the results of public consultations are not always as expected (or perhaps desired); some participation efforts have had a negative effect on resilience. Recently, consultations related to proposed Water Law amendments have led to the importance of the flood hazard and risk maps being downplayed. Their potential impact on spatial planning has decreased following the legislative amendment because the maps can but do not have to be taken into account (poz.2295, Water Law amendment 2015).

Furthermore, the FD has no discussion about how to facilitate transboundary participation (i.e., citizens' ability to comment on the worsening of their risks caused by FRM actions in other countries) unless proposed plans or projects fall within the scope of the Strategic or regular Environmental Impact Directive. Although this does not mean that effective transboundary participation is not occurring or will not occur, the lack of provision leaves it to the discretion of neighboring countries within a river basin, and as such, cross-border participation may be variable. A positive example, however, is provided by the case of Haparanda, Sweden, which shares a river border (River Torne) with the Torino municipality in Finland. Here, the consultation 
processes, as well as engaging Swedish consultees, also included both the Finnish-Swedish Transboundary River Commission and the Finnish authority with competences for the implementation of the FD (Johansson 2015a).

Stakeholders' access to justice in terms of enforcing their rights to participate in or challenge decisions is limited in the FD. Indeed, one recognized disadvantage of the FD's procedural approach is that it does not grant rights to citizens or empower them to challenge FRM decisions (Keessen and van Rijswick 2012). The programmatic approach selected results in the situation that citizens can only enforce their right that FRMPs are actually established, and not that appropriate FRM occurs (see Judgment of 25 July 2008, Janecek v. Freistaat Bayern, Case C-237/07, EU:C:2008 I-06221). Citizens do not have other recourses with respect to substantive issues stemming from the FD (Keessen and van Rijswick 2012). Each country relies on national rules for access to justice that will now be considered to judge whether implementation has been designed to offer sufficient possibilities for citizen enforcement.

In terms of access to justice, national implementation is quintessentially a result of the programmatic and procedural approach adopted by the FD. Therefore, citizens must rely on their national legislation for such opportunities, and it is pertinent to consider the potential for successful challenges. Analysis of the six countries has highlighted many similarities, and in general, opportunities for challenges are limited or difficult. Challenging decisions and bringing cases before an administrative court requires complaints to be specific, aimed at legal decisions and consequences, as well as affecting a person or company directly. Many of the aspects in the FD (such as the choice of risk maps and the way FRMPs are drafted) do not fulfil these requirements, which would argue for adding legal protection against these instruments in the FD. In some of the countries, the plans and programs may include more substantial decisions related to flood risk measures (e.g., the creation of dikes) or spatial planning decisions (e.g., plans that prescribe building prohibitions), which may be challenged before administrative courts. However, if permits and specific permissions are replaced by general rules, then there is little scope for citizen challenge. As such, the approach in the FD, by not specifically including provisions relating to access to justice and by not requiring the inclusion of substantive measures or legal instruments within the plans, is undermining and limiting the possibilities for challenging and the enforceability of its measures by private actors.

\section{Effectiveness in goal achievement: follow-up and enforcement}

The advantages of the flexible and adaptable EU flood risk approach may also hamper the effectiveness of the legal framework (OECD 2011, Keessen and van Rijswick 2012, Green et al. 2013). Although, in principle, the river-basin approach should enable coordinated FRM, in practice, this is not always the case, and management remains within national borders (Suykens 2015, Hartmann and Spit 2016). Keessen and van Rijswick (2012) propose various legal factors that may contribute to the continued persistence of national approaches, including differing interpretations of the concepts and obligations, institutional differences, and issues related to the inconsistency of responsibilities. The last of these is very important because there is a lack of shared responsibility and accountability for attaining transboundary management goals within the FD (van Rijswick et al. 2010). Compliance may also be a concern because EU law generally lacks legal basis for arbitration (Keessen and van Rijswick 2012), and the FD suggests nothing about the Commission's mediatory function other than it should respond within six months (e.g., art.8 FD). In addition to these legal factors, other variations in culture, public and political expectations, budgets, existing competencies, as well as the overarching ambitions and philosophies of FRM may also contribute to the observed continuation of national boundaries.

The national-level implementation reflects many of these aforementioned bottlenecks. In some situations, improving flood resilience is currently undermined by the lack of a consistent view of what the management goal should be. Positively, policy freedom might lead to the appropriate tailoring of approaches and account for levels of flood risk, FRM competences, and political priorities. However, this flexible approach to goal setting may create problems in a transboundary context and in enforcing the goals and objectives of one country. It will be difficult for a holistic river basin approach to be implemented if differing FRM measures and standards are adopted. Analysis of the FRMPs of the River Scheldt for three countries researched (France, Belgium [both Flanders and Wallonia], and the Netherlands) highlights some of these issues (Préfet Coordonnateur de Basin ArtoisPicardie 2015, CIW 2015, SPW 2015, Ministerie van Infrastructuur en Milieu 2015). Firstly, there is no agreement on a common definition of what constitutes a "significant increase" in risk and therefore no joint interpretation and consensus on what should be avoided (art.7(4) FD), leading to no reflection of the solidarity requirement included in the Directive. Furthermore, the overarching umbrella FRMP for this river basin (ISC 2014) does not mention these various different interpretations, and the individual country FRMPs have either presented different definitions or omitted it altogether. The Commission might have avoided these issues if some concepts had been defined or had clearer interpretations. Importantly, without such an agreement about what is or is not permitted, it is difficult to envisage how the FRMPs can be fully effective.

Secondly, the FD leaves room for each country to identify and set their own independent FRM objectives and allows the freedom to decide which specific measures to prioritize. These differences are evident in the plans to manage the risk of the Scheldt basin. The individual country plans mention multiple objectives related to different FRM strategies, but the emphasis of each is variable. Much of the focus in the Dutch plan is on flood prevention, whereas in the other plans, there is greater emphasis on spatial planning and preventing increasing development. Furthermore, neither the French nor Belgian FRMPs set minimum legal safety standards. In contrast, the Dutch FRMP has minimum standards of 1 in 4000 years for primary flood defenses (those along the sea, the estuary, and the River Scheldt). Specifically, for international river basin districts, it is important to assess these interjurisdictional differences when evaluating whether effective FRM is affected negatively.

In other countries, the FD has had a positive effect on achieving coordinated transboundary FRM goals. When the Swedish Civil Contingencies Agency conducted its preliminary assessment under the FD, Haparanda municipality was indicated as 
significantly vulnerable, at least in part, because the adjacent Finnish Tornio municipality had been identified as flood prone by the Finnish authorities (MSB 2011). The FRMP for Haparanda indicates performance objectives that are common or similar to those in the FRMP on the Finnish side (Johansson 2015a).

One of the effective obligations of the FD is that it requires all countries to undertake flood risk assessments and produce (and subsequently update) maps and plans on the same time frame. This will enable discrepancies in the understanding of flood risk between neighboring administrative units (within the same river basin) to be highlighted, and the concurrent planning process provides a better chance for integrated and coordinated FRM to result. These advantages have been observed in the River Odra basin (spanning the Czech Republic, Poland, and Germany) and the River Dunajec basin (shared between Slovakia and Poland), where information exchanged as part of the mapping and risk assessment process has improved mutual understanding and provided the opportunity to explore any discrepancies. Despite this, the FD does not go so far as to require that transboundary flood risk modeling be undertaken to ensure the comparability of risk assessments, although some river commissions may have, or could introduce, provisions for this.

\section{Diversification of flood risk management approaches}

In the FD, diversification of FRM approaches is championed and aims to promote the FRM strategies of prevention, protection, and preparedness (recital 14 FD). Here, we analyze the extent to which the national FRM approaches studied are sufficiently diversified and aligned. All six countries do have a diversified approach to FRM, but they differ in which strategies are prioritized and the degree to which the FD led to changes to the strategies adopted. The Dutch multilayered safety and risk-based approach is slightly different but consistent with the FD's diversification agenda. It is unclear which recent developments in FRM are directly due to the FD implementation, but interviews suggested the risk approach, which was already being developed, gained importance because of the FD, which hastened its implementation into formal legislation (Kaufmann et al. 2016). Similarly, in England, substantial changes in FRM did not emerge solely as a consequence of the FD (Alexander et al. 2016, Hegger et al. 2016). The implementation, in 2009, coincided with the adoption and integration of lessons from the independent review following the 2007 floods (Pitt 2008), and therefore, it is difficult to isolate changes specifically caused by or only by the FD.

Tensions have emerged in some cases between the expectations of countries and the Commission in terms of broadening FRM approaches. The FD sets the overarching objective of managing or reducing flood risk; however, the stance in Poland still relates to meeting more project-type goals rather than problem solving. Therefore, despite further development of approaches to prepare better for floods and the aim of preventing development in flood risk areas, structural solutions still dominate. In Poland, there remains an expectation that dikes should better protect urban areas and be adequately strengthened, but this protectiondominated approach has been criticized by the Commission.
Goodness of fit with existing national flood risk management This section explores the goodness of fit between the existing administrative structure prior to the adoption of the (WFD and) FD, and the new models provided therein, e.g., with respect to river basin management and the question of whether FRM approaches are sufficiently diversified and aligned. In terms of goodness of fit, in Flanders, the Decree Integrated Water Policy in 2003 had already begun a process of integrating water management and the implementation of FRM measures. In general, the FD's conditions fit into these existing legal requirements. However, it also initiated a further step toward more comprehensive FRM because the new three-step procedural requirements induced the Flemish region to develop policies and strategies further and move toward a risk-based approach.

In the Netherlands, the effect of the FD on national FRM policy has been minimal. This is primarily because of the goodness of fit between the existing domestic FRM policy and positive synergy between two of the key principles of the FD and national policy: "the solidarity principle and not passing floods to downstream regions" (van Eerd et al. 2015:200). In Poland, there is a conflict between the existing and continued preference for flood defenses and the FD's desire to promote diversified FRM approaches, illustrating potential problems with the goodness of fit. However, this should not be unexpected or necessarily viewed as negative. There is of course a tension between successful implementation of the FD, which is aided by a good fit with existing approaches, and its effects on FRM. For countries that had less advanced and developed FRM policy and practices, and hence, where the goodness of fit may be lower, the implementation of the FD may require more effort. However, greater change may be stimulated in these circumstances. Therefore, there is a balance required between enabling a successful adoption of any EU policy and the motivation of actual changes to flood resilience.

Summary of the evaluation of European Union level and national implementation in the six selected countries

In the key findings from an EU-level evaluation of the FD (Table $3)$, the approaches adopted offer wide policy discretion and adaptability for the way that countries want to manage flooding. The rules are adaptive because they prescribe assessments, monitoring, and participation to inform the coordinated, six-year planning cycle. This enables the specific and changing circumstances and societal needs within river basins to be addressed. Furthermore, the combination of competent authorities and administrative arrangements per river basin district and the requirement of public participation constitute positive and resilient institutional elements. However, this open and flexible formulation of goals and objectives may hamper enforcement. Keessen and van Rijswick (2012) argue that the aim of reducing adverse flood effects (art.1 FD) comprises an obligation of best efforts, rather than enforceable goals. The FD leaves much room for countries to shape FRM and, as such, its effect on flood resilience will be driven primarily by national implementation and practice. The analysis of the national-level implementation of the FD reflects the evaluation at the EU level (Table 4). 
Table 4. Evaluation of the national implementation of the Floods Directive (FD) in six European countries.

\begin{tabular}{|c|c|c|c|c|c|}
\hline $\begin{array}{l}\text { Criterion } \\
\quad \text { Belgium (Flanders) }\end{array}$ & England & France & The Netherlands & Poland & Sweden \\
\hline \multicolumn{6}{|c|}{ Multilevel governance at the bioregional scale } \\
\hline $\begin{array}{l}\text { Strongly integrated } \\
\text { water management; } \\
\text { ineffective river basin } \\
\text { approach to } \\
\text { transboundary river } \\
\text { management }\end{array}$ & $\begin{array}{l}\text { River basin approach } \\
\text { followed; local-scale } \\
\text { responsibilities } \\
\text { strengthened and } \\
\text { clarified in part } \\
\text { because of FD; recent } \\
\text { development toward } \\
\text { greater alignment of } \\
\text { flood risk management } \\
\text { functions }\end{array}$ & $\begin{array}{l}\text { Flood risk management plans } \\
\text { adopted by the basin Prefect } \\
\text { (State) with consultation } \\
\text { from river basin committees; } \\
\text { flood risk management } \\
\text { largely implemented at the } \\
\text { local scale (municipalities or } \\
\text { intermunicipal bodies), with } \\
\text { sub-basin collaboration being } \\
\text { discretionary }\end{array}$ & $\begin{array}{l}\text { Strongly integrated water } \\
\text { management at all levels; } \\
\text { appropriate coordination } \\
\text { mechanisms between national } \\
\text { and regional levels; water } \\
\text { authorities have little } \\
\text { influence over spatial } \\
\text { planning decisions }\end{array}$ & $\begin{array}{l}\text { River basin approach } \\
\text { followed, but some } \\
\text { disparity remains } \\
\text { between administrative } \\
\text { borders and river } \\
\text { basins }\end{array}$ & $\begin{array}{l}\text { Limited integration in } \\
\text { water management (see } \\
\text { e.g., Johannessen and } \\
\text { Granit 2015) }\end{array}$ \\
\hline \multicolumn{6}{|c|}{ (2) } \\
\hline $\begin{array}{l}\text { Multilayered water } \\
\text { safety allows adoption } \\
\text { of new policy choices } \\
\text { and insights; reform of } \\
\text { Decree Integrated } \\
\text { Water Policy in } 2013 \text { to } \\
\text { integrate more } \\
\text { flexibility in planning }\end{array}$ & $\begin{array}{l}\text { Established cultures of } \\
\text { institutional learning } \\
\text { present; system } \\
\text { dominated by } \\
\text { incremental policy } \\
\text { change }\end{array}$ & $\begin{array}{l}\text { After consulting the river } \\
\text { basin committee, a Prefect } \\
\text { can change a flood risk } \\
\text { management plan but must } \\
\text { ensure the objectives remain } \\
\text { unchanged; adaptation to } \\
\text { climate change is only a } \\
\text { discretionary reason for a } \\
\text { change (no obligation) }\end{array}$ & $\begin{array}{l}\text { Water Framework Directive } \\
\text { and FD changed the } \\
\text { planning cycle from } 4 \text { to } 6 \\
\text { years but did not change the } \\
\text { possibility to learn from and } \\
\text { adapt flood risk management } \\
\text { policies; monitoring cycle of } \\
\text { flood defenses changed from } \\
6 \text { to } 12 \text { years; large } \\
\text { investment in research funds }\end{array}$ & $\begin{array}{l}\text { Positive introduction } \\
\text { of iterative processes } \\
\text { since FD, rather than } \\
\text { past reliance on shock } \\
\text { events to motivate } \\
\text { change }\end{array}$ & $\begin{array}{l}\text { Iterative and integrated } \\
\text { approach of FD will } \\
\text { likely have positive } \\
\text { effects in relation to } \\
\text { knowledge about flood } \\
\text { risks and flood risk } \\
\text { management }\end{array}$ \\
\hline \multicolumn{6}{|c|}{ Effective public participation and access to justice } \\
\hline $\begin{array}{l}\text { Well-institutionalized } \\
\text { public participation } \\
\text { and information } \\
\text { disclosure; } 6 \text { month } \\
\text { public inquiry for } \\
\text { flood risk management } \\
\text { plan but unclear how } \\
\text { results are used; } \\
\text { sufficient access to } \\
\text { justice, but efficiency is } \\
\text { dependent on the type } \\
\text { of procedure; access to } \\
\text { justice for flood risk } \\
\text { management plans } \\
\text { more limited by lack of } \\
\text { substantive or binding } \\
\text { outcomes }\end{array}$ & $\begin{array}{l}\text { High degrees of public } \\
\text { participation well } \\
\text { institutionalized; } \\
\text { access to justice of } \\
\text { citizens follow general } \\
\text { rules; in reality, time } \\
\text { consuming and } \\
\text { expensive }\end{array}$ & $\begin{array}{l}\text { Flood risk management plan- } \\
\text { related public participation is } \\
\text { considered weak; no public } \\
\text { inquiry organized; } 6 \text { months } \\
\text { to provide written comment, } \\
\text { but no reaction to how these } \\
\text { were taken into account; } \\
\text { access to justice hampered by } \\
\text { lack of substantive or } \\
\text { binding outcomes }\end{array}$ & $\begin{array}{l}\text { Sufficient opportunity for } \\
\text { participation, but } \\
\text { undermined by low } \\
\text { awareness of flood risk and } \\
\text { thus interest to participate; } \\
\text { access to justice limited to } \\
\text { certain decisions about } \\
\text { certain spatial plans and } \\
\text { flood risk management } \\
\text { measures }\end{array}$ & $\begin{array}{l}\text { Broader public } \\
\text { consultation, but not } \\
\text { necessarily all with } \\
\text { positive effect on } \\
\text { increasing flood } \\
\text { resilience; principal } \\
\text { access to justice exists, } \\
\text { but limited in reality }\end{array}$ & $\begin{array}{l}\text { Institutionalized public } \\
\text { participation; early } \\
\text { consultation with } \\
\text { municipalities; access to } \\
\text { justice subject to } \\
\text { general rules, limited by } \\
\text { lack of substantive or } \\
\text { binding outcomes }\end{array}$ \\
\hline \multicolumn{6}{|c|}{ Effectiveness in goal achievement: follow-up and enforcement } \\
\hline $\begin{array}{l}\text { Enforcement } \\
\text { recognized as a } \\
\text { concern; efforts } \\
\text { ongoing to strengthen } \\
\text { enforcement for } \\
\text { integrated water } \\
\text { policies }\end{array}$ & $\begin{array}{l}\text { Little change to } \\
\text { existing legal } \\
\text { framework; no obvious } \\
\text { legal barriers to } \\
\text { effectiveness, but also } \\
\text { few changes addressing } \\
\text { existing weakness }\end{array}$ & $\begin{array}{l}\text { Although flood risk } \\
\text { management plans have } \\
\text { direct legal effects on town } \\
\text { planning and water } \\
\text { management decisions and } \\
\text { compatibility between plans } \\
\text { is mandated, in practice the } \\
\text { legal effects of flood risk } \\
\text { management plans are weak }\end{array}$ & $\begin{array}{l}\text { Well-developed system of } \\
\text { monitoring for water and } \\
\text { flood risk management, } \\
\text { including legal } \\
\text { responsibilities in case of } \\
\text { goal failure; enforcement } \\
\text { generally limited to public } \\
\text { actors (water authorities); } \\
\text { monitoring of spatial } \\
\text { planning less common, but } \\
\text { improving }\end{array}$ & $\begin{array}{l}\text { Continuous iteration } \\
\text { of legal framework; } \\
\text { not all modifications } \\
\text { have been positive; } \\
\text { legislative change in } \\
2015 \text { potentially } \\
\text { reduced effectiveness } \\
\text { of spatial planning } \\
\text { decisions in reducing } \\
\text { risk }\end{array}$ & $\begin{array}{l}\text { Flood risk management } \\
\text { plans not legally } \\
\text { binding; effectiveness } \\
\text { will likely build on } \\
\text { collaboration of actors } \\
\text { during development of } \\
\text { flood risk management } \\
\text { plans }\end{array}$ \\
\hline \multicolumn{6}{|l|}{ Goodness of fit } \\
\hline $\begin{array}{l}\text { Prior existence of } \\
\text { measures; FD } \\
\text { strengthened legal } \\
\text { framework and flood } \\
\text { policy }\end{array}$ & $\begin{array}{l}\text { FD fits well with } \\
\text { existing policies and } \\
\text { diversity of } \\
\text { approaches }\end{array}$ & $\begin{array}{l}\text { Fits with existing approach, } \\
\text { but distribution of power } \\
\text { does not match the } \\
\text { bioregional approach }\end{array}$ & $\begin{array}{l}\text { FD fits well with existing } \\
\text { policies; risk-based approach } \\
\text { being adopted in line with } \\
\text { FD requirements }\end{array}$ & $\begin{array}{l}\text { Continued dominance } \\
\text { of structural defense } \\
\text { criticized by European } \\
\text { Commission }\end{array}$ & $\begin{array}{l}\text { FD does not } \\
\text { significantly alter } \\
\text { existing organization } \\
\text { and responsibilities for } \\
\text { flood risk management }\end{array}$ \\
\hline \multicolumn{6}{|l|}{ Diversification } \\
\hline $\begin{array}{l}\text { Multilayered water } \\
\text { safety approach; in } \\
\text { addition to defense, } \\
\text { increasing attention to } \\
\text { prevention and } \\
\text { mitigation; at federal } \\
\text { level, preparedness and } \\
\text { recovery also } \\
\text { important }\end{array}$ & $\begin{array}{l}\text { Flood risk } \\
\text { management } \\
\text { traditionally been } \\
\text { diverse, and this } \\
\text { remains the case } \\
\text { postimplementation }\end{array}$ & $\begin{array}{l}\text { Diversification evident } \\
\text { although approaches are } \\
\text { unbalanced; Flood Risk } \\
\text { Prevention Plan focused on } \\
\text { prevention remains most } \\
\text { important, and its strong } \\
\text { legal effect is limiting } \\
\text { diversification }\end{array}$ & $\begin{array}{l}\text { Movement toward more } \\
\text { diversification: risk-based } \\
\text { approach and multilayered } \\
\text { safety will be further } \\
\text { developed; path dependency } \\
\text { and sunk costs means still } \\
\text { dominated by defense; } \\
\text { greater attention should be } \\
\text { paid to urban flooding }\end{array}$ & $\begin{array}{l}\text { Traditionally } \\
\text { dominated by } \\
\text { structural defenses, but } \\
\text { prevention and } \\
\text { preparation are on the } \\
\text { increase }\end{array}$ & $\begin{array}{l}\text { Traditionally focused } \\
\text { on preparation, } \\
\text { recovery, and defense; it } \\
\text { was expected that } \\
\text { knowledge-increasing } \\
\text { measures would } \\
\text { predominate in the first } \\
\text { cycle of flood risk } \\
\text { management plans }\end{array}$ \\
\hline
\end{tabular}




\section{KEY FINDINGS: EFFECT OF THE FLOODS DIRECTIVE ON INCREASING RESILIENCE TO FLOODING}

Based on our analysis of the EU Floods Directive and the six national flood risk management policies and legal frameworks, lessons can be construed. The following six considerations related to the implementation of the FD result.

Governance at the bioregional scale and integration: There are clearly some examples whereby transboundary cooperation and understanding has been stimulated by requirements of the FD (e.g., the Torne, Oder, and Dunajec rivers). However, in other shared river basin districts, FRM in Europe is still far from a systematic coordination of actions, as the Scheldt River basin case shows. A lack of consensus about important FD definitions and concepts may hamper successful transboundary flood management. A lack of coordination reduces synergy because it makes it difficult to assess which combination of flood strategies (see Hegger et al. 2014, Gilissen et al. 2016, Suykens et al. 2016) may work best within the whole river basin district. The enforceability of the content of joint FRMPs is questionable and depends exclusively on the good will of the respective countries and regions. The FRMP rather constitutes a blueprint for information exchange. Rather than concentrating coordination on FRM objectives and outcomes, there is a tendency merely to list relevant national measures with transboundary effects and methodologies for identifying flood risks. Therefore, although better coordination is a step in the right direction, it is difficult to see how the approach will be able to deliver better transboundary outcomes. In terms of integration and coordination between the FD and the WFD, there is variability between the countries analyzed.

It is expected that further harmonization between the two Directives may emerge as the timescales of planning and review are synchronized, although Evers and Nyberg (2013) indicate that a lack of consistency between the Directives may remain a barrier. The FD currently does little to facilitate additional intersectoral coordination such as between FRM and, for instance, the Common Agricultural Policy, nature conservation measures, and the ecological restoration of waterways, which also may reduce flood risks or their effects.

Adaptability: FRMPs have the potential to change practice at the river basin, regional, and local levels. A prerequisite for successful adaptability is that competent authorities duly take into account lessons learned stemming from periodic reviews and monitoring (Clarvis et al. 2014). This is an aspect in which the EU level potentially has a very powerful role. The six-year planning cycle provides a clear foundation for adaptive learning; however, there are no requirements to demonstrate that lessons have led to change or improved FRM. Furthermore, the minimum requirement for review is six-years, which if this is the only learning opportunity undertaken by competent authorities, is a considerable period and may delay necessary changes to FRM actions or priorities.

Public participation and access to justice: Another consequence of the procedural approach adopted by the FD relates to legitimacy concerns. The FD does not offer citizens a minimum level of flood protection (comparable to external safety, as regulated under the Seveso directives), but merely focuses on the availability of flood risk information and the obligation for the
Member States to develop FRMPs that contain measures to achieve appropriate but self-set objectives. Firstly, it is not clear what "appropriate" means because the FD gives no guidance on the meaning and scope. Secondly, it is thus not clear whether the provisions and requirements set forth in the FD are challengeable by citizens. For instance, are citizens able to ask for areas to be included, removed, or changed on a flood risk map or to force the implementation of different measures? The current focus in EU water law is primarily on the beginning of the policy cycle, where the involvement of citizens has to be encouraged (FD and WFD). Increased attention should be paid to the end of the policy cycle and, crucial for effectiveness, on the enforceability of objectives not only by public actors but also by private citizens because it is their safety, in the end, that is at stake.

Effectiveness in goal achievement: The procedural character of the FD raises doubts about its effectiveness on a substantive level. The effectiveness of the Directive's goals will depend on the ambition of competent authorities within Member States. The existence of policy discretion is a key characteristic of the Directive; the FD does not require specific outcomes, set a standard level of protection, or provide directives on the prioritization of measures. Therefore, goal attainment will depend on both the way the open and flexible aims are elaborated into more specific management objectives at the national, regional, and local levels and the extent to which Member States use their discretion to guarantee flood safety, prevention, or vulnerability reduction for their citizens and actually adopt and finance FRM measures. Therefore, the answer to the question of whether the FD increases societal resilience in the Member States may be highly variable. This is especially the case in the transboundary context. However, despite questions related to the enforceability and effectiveness on a substantive level, the Directive is, in all cases, inducing thorough consideration of flood risk issues. This is especially relevant to those locations and countries where such consideration was lacking in the preexisting frameworks. The question also arises whether and which authorities have the competence to enforce FD provisions within the national context.

Within the current legal and institutional constellation, the European Commission plays the most important role in enforcing FD compliance. It will take several years before the Commission can undertake action in this field because it is only after time that it will be clear what the effects of this adaptive governance approach are in reducing flood risks and increasing resilience. At this point, i.e., at the time of promulgation of the FRMPs, the main recourse of action available to the Commission relates to infringement procedures for non- or late submission of the plans. In addition, ensuring compliance with the FD is just one of the many tasks of the European Commission, and political prioritization will determine how much effort it may expend.

Diversification of flood risk management approaches and effect of the FD on legal systems: There are substantial differences in the effects that the FD has had on the applicable legal and policy frameworks of countries in which it is implemented. On opposite sides of the spectrum are Poland vs. England and the Netherlands. In Poland, the Directive has had a strong effect in the creation of legal instruments for FRM and has led to a diversification of strategies. In England and the Netherlands, the effect has been minimal because of a solid package of preexisting FRM legal 
instruments and measures and a goodness of fit with the requirements of the FD. In Sweden, the FD introduced the first legal instrument specifically for FRM, but the ordinance seeks only to meet the formal implementation requirements, rather than taking a more ambitious approach. However, the FD has stimulated greater interest in, and discussion about, FRM in Sweden at a national level. Belgium and France both had a legal framework for FRM prior to the entry into force of the FD, but the FD it has strengthened this framework, through the compliance with the three procedural phases, and further induced diversification of strategies. The FD constitutes an example of the principle of subsidiarity anchored in primary and secondary EU law. Indeed, even though a Directive that sets forth requirements to be implemented by Member States can be considered a top-down instrument, the FD cannot be considered as adopting a true top-down approach. Much legal and policy discretion remains with Member States in choosing and implementing FRM strategies and measures. In this sense, the FD allows for bottom-up management, but perhaps could do more to promote local initiatives.

Goodness of fit: Implementation challenges will always be greatest in situations where goodness of fit is low. However, it is in those situations where the requirements of the FD may be needed and where improvements to flood risk resilience will be most pronounced. Such countries may require additional guidance, resources, or time to move toward greater resilience. There is also a danger in these cases that the FD's lack of substantive requirements might mean that implementing changes to FR measures that improve flood resilience takes considerably longer to emerge or lacks coherence with measures in other EU Member States. This is especially delicate when such countries are situated in the same international river basin district.

\section{CONCLUDING REMARKS}

Our analysis indicates that the effect of the FD is highly variable among the six European countries, and this variability may be highly problematic in the context of international river basin districts. A combined legal and policy approach has enabled insight into how the FD has been implemented and legally embedded into existing frameworks. Additionally, opportunities and barriers for its effectiveness in influencing societal flood resilience have been identified, as well as the current and potential effects on flood risk policy. Our research includes a varied mix of countries with a variety of legal frameworks, levels of flood risk, and differing experiences, competencies, and traditions of FRM. Therefore, many of the findings and recommendations concerning whether the FD will successfully enhance flood resilience are applicable to the wider international context.

The flexibility inherent within the FD means that it is up to the discretion and commitment of each separate country or FRM authority whether FRM will ultimately be strengthened. The lack of substantive obligations means that as long as a country fulfills the assessment and planning obligations set out in the FD, it is in compliance with EU requirements. Strictly speaking, this implies that it is possible to satisfy requirements without making any substantial changes to flood risk or FRM outcomes. In reality, however, it is expected that most countries will begin to undertake the measures prioritized in the FRMPs and increase societal resilience, and that the six-year planning cycle required by the FD will motivate them to do so. However, it is too soon to evaluate fully the effect of this key instrument on flood resilience, and how these plans develop into action remains a critical area for future research. The EU could strengthen the FD requirements, particularly in the context of transboundary rivers, by requiring more stringent cooperation such as subjecting the states sharing international river basin districts to an obligation of result of rendering the promulgation of one single international FRMP pursuant to the FD and river basin management plan pursuant to the WFD for international river basin districts, instead of an obligation of best effort. It could also strengthen the FD requirements by revisiting the legal tools available to the states to concretize their duties to cooperate in the implementation of the Directives.

Despite the shortcomings of the FD in directly affecting flood risk outcomes, it has had a positive influence in stimulating discussion and flood risk management planning in Member States that were perhaps lagging behind. An increased understanding and awareness of flood risk issues, generated through the compulsory elements of flood risk assessment and mapping, are fundamental precursors to improving management approaches and are components that should be the foundation for FRM in any international context. Similar to the obligation in the WFD, the FD can be viewed as a stimulus to begin transboundary flood risk discussion and cooperation, and the development of a common framework (with harmonized managerial timescales) provides, at the least, a mutual basis for the improvement of flood risk management.

Responses to this article can be read online at: http://www.ecologyandsociety.org/issues/responses. $\mathrm{php} / 8913$

\section{Acknowledgments:}

The work described in this publication was supported by the European Community's Seventh Framework Program through the grant to the budget of the STAR-FLOOD project (Grant Agreement 308364). The authors thank the anonymous reviewers and Subject Editor for their constructive comments about this paper.

\section{LITERATURE CITED}

Alexander, M., S. Priest, A. P. Micou, S. Tapsell, C. Green, D. Parker, and S. Homewood. 2016. Analysing and evaluating flood risk governance in England: enhancing societal resilience through comprehensive and aligned flood risk governance arrangements. STAR-FLOOD Consortium. Flood Hazard Research Centre, Middlesex University, London, UK. [online] URL: http://www. starflood.eu/documents/2016/03/wp3-en-final-webversion.pdf

Beijen, B. A., H. F. M. W. van Rijswick, and H. T. Anker. 2014. The importance of monitoring for the effectiveness of environmental directives: a comparison of monitoring obligations in European environmental directives. Utrecht Law Review 10(2):126-135. http://doi.org/10.18352/ulr.273

Bell, S., D. McGillivray, and O. W. Pedersen. 2013. Environmental law. Eighth edition. Oxford University Press, Oxford, UK. http:// dx.doi.org/10.1093/he/9780199583805.001.0001 
Buijze, A. W. G. J. 2009. Effectiviteit in het bestuursrecht. Nederlands Tijdschrift voor Bestuursrecht 8:228-237.

Carpenter, S., B. Walker, J. M. Anderies, and N. Abel. 2001. From metaphor to measurement: Resilience of what to what? Ecosystems 4(8):768-781. http://dx.doi.org/10.1007/s10021-001-0045-9

Chaffin, B. C., H. Gosnell, and B. A. Cosens. 2014. A decade of adaptive governance scholarship: synthesis and future directions. Ecology and Society 19(3):56. http://dx.doi.org/10.5751/ ES-06824-190356

CIW (Coördinatiecommissie Integraal Waterbeleid). 2015. Stroomgebiedbeheerplan voor de Schelde en Maas 2016’2021. Coördinatiecommissie Integraal Waterbeleid, Aalst, Belgium. [online] URL: http://www.integraalwaterbeleid.be/nl/ stroomgebiedbeheerplannen/stroomgebiedbeheerplannen-2016-2021/ stroomgebiedbeheerplannen-voor-schelde-en-maas-2016-2021

Clarvis, M. H., A. Allan, and D. M. Hannah. 2014. Water, resilience and the law: from general concepts and governance design principles to actionable mechanisms. Environmental Science and Policy 43:98-110. http://dx.doi.org/10.1016/j. envsci.2013.10.005

Cosens, B. 2010. Transboundary river governance in the face of uncertainty: resilience theory and the Columbia River Treaty. Journal of Land, Resources, and Environmental Law 30 (2):229-265.

Cosens, B., L. Gunderson, C. Allen, and M. H. Benson. 2014. Identifying legal, ecological and governance obstacles, and opportunities for adapting to climate change. Sustainability 6 (4):2338-2356. http://dx.doi.org/10.3390/su6042338

Cosens, B. A., and M. K. Williams. 2012. Resilience and water governance: adaptive governance in the Columbia River basin. Ecology and Society 17(4):3. http://dx.doi.org/10.5751/ES-04986-170403

Dietz, T., E. Ostrom, and P. C. Stern. 2003. The struggle to govern the commons. Science 302(5652):1907-1912. http://dx.doi. org/10.1126/science.1091015

Djalante, R., C. Holley, and F. Thomalla. 2011. Adaptive governance and managing resilience to natural hazards. International Journal of Disaster Risk Sciences 2(4):1-14. http:// dx.doi.org/10.1007/s13753-011-0015-6

Ebbesson, J. 2010. The rule of law in governance of complex socioecological changes. Global Environmental Change 20(3):414-422. http://dx.doi.org/10.1016/j.gloenvcha.2009.10.009

EC (European Commission). 2003. Common implementation strategy for the Water Framework Directive (2000/60/EC): guidance document no 8: public participation in relation to the Water Framework Directive. Office for Official Publications of the European Communities, Luxembourg City, Luxembourg. [online] URL: https://circabc.europa.eu/sd/a/0fc804ff-5fe6-4874-8e0dde3e47637a63/Guidance $\% 20$ No $\% 208 \% 20-\% 20$ Public $\% 20$ participation $\%$ 20(WG\%202.9).pdf

EC (European Commission). 2004. Communication from the Commission to the Council, the European Parliament, the European Economic and Social Committee and the Committee of the Regions: flood risk management: flood prevention, protection and mitigation. Brussels, 12.07.2004, COM (2004)472 final. Office for Official Publications of the European Communities, Luxembourg City, Luxembourg. [online] URL: http://eur-lex. europa.eu/legal-content/EN/TXT/?uri=CELEX:52004DC0472

EC (European Commission). 2006. Proposal for a directive of the European Parliament and of the Council on the assessment and management of floods. Brussels, 18.01.2006, COM(2006)15 final. Office for Official Publications of the European Communities, Luxembourg City, Luxembourg. [online] ULR: http://eur-lex. europa.eu/legal-content/EN/TXT/?uri=CELEX:52006PC0015

EC (European Commission). 2007. Directive 2007/60/EC of the European Parliament and of the Council of 23 October 2007 on the assessment and management of flood risks. Official Journal of the European Union, L 288:27-34. Office for Official Publications of the European Communities, Luxembourg City, Luxembourg. [online] URL: http://eur-lex.europa.eu/legal-content/EN/TXT/? uri=CELEX:32007L0060

EC (European Commission). 2009. Commission staff working document accompanying the white paper: adapting to climate change: towards a European framework for action: climate change and water, coasts and marine issues. Brussels, 01.04.2009, SEC (2009)386. Office for Official Publications of the European Communities, Luxembourg City, Luxembourg. [online] URL: http://eur-lex.europa.eu/LexUriServ/LexUriServ.do?uri=SEC:2009:0386: FIN:EN:PDF

EC (European Commission). 2015. Commission staff working document: report on the progress in implementation of the Floods Directive: accompanying the document: communication from the commission to the European Parliament and the Council: the Water Framework Directive and the Floods Directive: actions towards the 'good status' of EU water and to reduce flood risks. 09.03.2015, SWD(2015)51 final. Office for Official Publications of the European Communities, Luxembourg City, Luxembourg. [online] URL: http://ec.europa.eu/environment/water/waterframework/pdf/4th_report/CSWD $\% 20$ Report $\% 20$ on $\% 20$ the $\% 20$ FD $\%$ 20.pdf

EC (European Commission). 2016. EU overview of methodologies used in preparation of flood hazard and flood risk maps. Final report. Publications Office of the European Union, Luxembourg City, Luxembourg. http://dx.doi.org/10.2779/204606

Ek, K., S. Goytia, M. Pettersson, and E. Spegel. 2016. Analysing and evaluating flood risk governance in Sweden: adaptation to climate change? STAR-FLOOD Consortium, Utrecht, The Netherlands. [online] ULR: http://www.starflood.eu/documents/2016/03/ wp3-sw-final-webversion.pdf

Environment Agency. 2015. Acting on your responses to the draft update to the river basin management plan and flood risk management plan consultations 2015. Environment Agency, Bristol, UK. [online] URL: https://www.gov.uk/government/ uploads/system/uploads/attachment_data/file/496505/12i_FINAL Jan 2016.pdf

Evers, M., and L. Nyberg. 2013. Coherence and inconsistency of European instruments for integrated river basin management. International Journal of River Basin Management 11(2):139-152. http://dx.doi.org/10.1080/15715124.2013.811416 
Folke, C. 2006. Resilience: the emergence of a perspective for social-ecological systems analyses. Global Environmental Change 16(3):253-267. http://dx.doi.org/10.1016/j.gloenvcha.2006.04.002

Folke, C., T. Hahn, P. Olsson, and J. Norberg. 2005. Adaptive governance of social-ecological systems. Annual Review of Environment and Resources 30:441-473. http://dx.doi.org/10.1146/ annurev.energy.30.050504.144511

Garmestani, A. S., and M. H. Benson. 2013. A framework for resilience-based governance of social-ecological systems. Ecology and Society 18(1):9. http://dx.doi.org/10.5751/ES-05180-180109

Gilissen, H. K., M. Alexander, J.-C. Beyers, P. Chmielewski, P. Matczak, T. Schellenberger, and C. Suykens. 2016. Bridges over troubled waters: an interdisciplinary framework for evaluating the interconnectedness within fragmented domestic flood risk management systems. Journal of Water Law 25(1):12-26.

Goytia, S., M. Pettersson, T. Schellenberger, W. J. van DoornHoekveld, and S. Priest. 2016. Dealing with change and uncertainty within the regulatory frameworks for flood defense infrastructure in selected European countries. Ecology and Society 21(4):23. https://doi.org/10.5751/ES-08908-210423

Green, O. O., A. S. Garmestani, H. M. F. W. Van Rijswick, and A. M. Keessen. 2013. EU water governance: striking the right balance between regulatory flexibility and enforcement? Ecology and Society 18(2):10. http://dx.doi.org/10.5751/ES-05357-180210

Gunderson, L., and C. S. Holling. 2002. Panarchy: understanding transformations in human and natural systems. Island Press, Washington, D.C., USA.

Hartmann, T., and T. Spit. 2016. Implementing the European flood risk management plan. Journal of Environmental Planning and Management 59(2):360-377. http://dx.doi.org/10.1080/0964$\underline{0568.2015 .1012581}$

Hedelin, B. 2016. The EU floods directive in Sweden: opportunities for integrated and participatory flood risk planning. Journal of Flood Risk Management, in press. http://dx. doi.org/10.1111/jfr3.12162

Hegger, D. L. T., P. P. J. Driessen, and M. H. N. Bakker, editors. 2016. A view on more resilient flood risk governance: key conclusions of the STAR-FLOOD project. STAR-FLOOD consortium, Utrecht, The Netherlands. [online] URL: http:// www.starflood.eu/documents/2016/03/d6-4-final-report-webversion. pdf

Hegger, D. L. T., P. P. J. Driessen, C. Dieperink, M. Wiering, G. T. T. Raadgever, and H. M. F. W. van Rijswick. 2014. Assessing stability and dynamics in flood risk governance. Water Resources Management 28(12):4127-4142. http://dx.doi.org/10.1007/s11269-014-0732$\underline{\mathrm{X}}$

Herman, C. 2010. Will the Floods Directive keep our feet dry? Policies and regulations in the Flemish Region and Scotland. Journal of Water Law 21(4):156-166.

Howarth, W. 2007. The European Community approach to flood defence. Journal of Water Law 18(4):115-116.

Huitema, D., E. Mostert, W. Egas, S. Moellenkamp, C. PahlWostl, and R. Yalcin. 2009. Adaptive water governance: assessing the institutional prescriptions of adaptive (co-)management from a governance perspective and defining a research agenda. Ecology and Society 14(1):26. [online] URL: http://www.ecologyandsociety. org/vol14/iss1/art26/

ISC (Internationale Scheldecommissie). 2014. Overkoepelend deel van het overstromingsrisicobeheerplan voor het internationale scheldestroomgebiedsdistrict. International Scheldt Commission, Antwerp, Belgium. [online] URL: http://www.isc-cie.org/images/ Documents/ODB1-PFPG1 ROR-DRI def.pdf

Jans, J. H., R. de Lange, S. Prechal, and R. J. G. M. Widdershoven. 2007. Europeanisation of public law. Europa Law Publishing, Groningen, The Netherlands.

Johannessen, Å., and J. J. Granit. 2015. Integrating flood risk, river basin management and adaptive management: gaps, barriers and opportunities, illustrated by a case study from Kristianstad, Sweden. International Journal of Water Governance 3(2015):5-24.

Johansson, E. B. 2015a. Riskhanteringsplan gällande översvämningsrisk i Haparanda. Rapportserie 1/2015. Länsstyrelsen Norrbotten, Luleå, Sweden. [online] URL: http://www.lansstyrelsen.se/ Norrbotten/Sv/publikationer/2015/Pages/riskhanteringsplan-gallandeoversvamningsrisk-i-haparanda.aspx

Johansson, E. B. 2015b. Riskhanteringsplan gällande översvämningsrisk i Älvsbyn. Rapportserie 6/2015. Länsstyrelsen Norrbotten, Luleå, Sweden. [online] URL: http://www.lansstyrelsen.se/norrbotten/ SiteCollectionDocuments/Sv/publikationer/manniska $\% 20$ och $\%$ 20samhalle/Krishantering/Riskhanteringsplan-gallandeoversvamningsrisk-i-Alvsbyn.pdf

Jongman, B., S., Hochrainer-Stigler, L. Feyen, J. C. J. H. Aerts, R. Mechler, W. J. W. Botzen, L. M. Bouwer, G. Pflug, R. Rojas, and P. J. Ward. 2014. Increasing stress on disaster-risk finance due to large floods. Nature Climate Change 4:264-268. http://dx.doi. org/10.1038/nclimate2124

Kaufmann, M., W. J. van Doorn-Hoekveld, H. K. Gilissen, and H. F. M. W. van Rijswick. 2016. Analysing and evaluating flood risk governance in the Netherlands: drowning in safety? STARFLOOD Consortium, Utrecht, The Netherlands. [online] URL: http://www.starflood.eu/documents/2016/03/wp3-nl-final-webversion. pdf

Keessen, A. M., J. J. H. van Kempen, M. van Rijswick, J. Robbe, and C. W. Backes. 2010. European river basin districts: Are they swimming in the same implementation pool? Journal of Environmental Law 22(2):197-222. http://dx.doi.org/10.1093/jel/ $\underline{\text { eqq003 }}$

Keessen, A. M., and H. F. M. W. van Rijswick. 2012. Adaptation to climate change in European water law and policy. Utrecht Law Review 8(3):38-50. http://dx.doi.org/10.18352/ulr.204

Länsstyrelsen Skåne. 2015. Riskhanteringsplan: Översvämning av Helge å $i$ Kristianstad tätort. Länsstyrelsen Skåne, Malmö, Sweden. [online] URL: http://www.lansstyrelsen.se/skane/ SiteCollectionDocuments/Sv/publikationer/2015/Riskhanteringsplan $\%$ 20Kristianstad.pdf

Larrue, C., S. Bruzzone, L. Lévy, M. Gralepois, T. Schellenberger, J. B. Trémorin, M. Fournier, C. Manson, and T. Thuilier. 2016. Analysing and evaluating flood risk governance in France: from 
state policy to local strategies. STAR-FLOOD Consortium, Tours, France. [online] URL: http://www.starflood.eu/documents/2016/03/ wp3-fr-final-webversion.pdf

Matczak, P., J. Lewandowski, A. Choryński, M. Szwed, and Z. W. Kundzewicz. 2016. Analysing and evaluating flood risk governance in Poland: looking for strategic planning in a country in transition. STAR-FLOOD Consortium, Utrecht, The Netherlands. [online] URL: http://www.starflood.eu/documents/2016/03/ wp3-poland-final-webversion.pdf

Mees, H., C. Suykens, J. C. Beyers, A. Crabbé, B. Delvaux, and K. Deketelaere. 2016. Analysing and evaluating flood risk governance in Belgium: dealing with flood risks in an urbanised and institutionally complex country. STAR-FLOOD Consortium, University of Antwerp, Antwerp, and KU Leuven, Leuven, Belgium. [online] URL: http://www.starflood.eu/documents/2016/03/ wp3-be-final-webversion.pdf

Ministerie van Infrastructuur en Milieu. 2015. Overstromingsrisicobeheerplan voor het stroomgebied van de Schelde 2016-2021: doelen en maatregelen voor het beheersen van overstromingsrisico's. Ministerie van Infrastructuur en Milieu, The Hague, The Netherlands. [online] URL: https://www.rijksoverheid.nl/ documenten/beleidsnota-s/2015/12/14/overstromingsrisicobeheerplanvoor-het-stroomgebied-van-de-schelde-2016-2021

MSB (Myndigheten för samhällsskydd och beredskap). 2011. Identifiering av områden med betydande översvämningsrisk: steg 1 i förordningen (2009:956) om översvämningsrisker - preliminär riskbedömning. Diarienummer 2011-2996. Myndigheten för samhällsskydd och beredskap, Karlstad, Sweden. [online] URL: https://www.msb.se/Upload/Nyheter press/Pressmeddelanden/ Slutrapport_PFRA_MSB.pdf

MSB (Myndigheten för samhällsskydd och beredskap). 2014. Vägledning för riskhanteringsplaner: enligt förordningen om översvämningsrisker (SFS 2009:956) samt MSB:s föreskrift om riskhanteringsplaner (MSBFS 2013:1). Myndigheten för samhällsskydd och beredskap, Karlstad, Sweden. [online] URL: https://www.msb.se/Upload/Forebyggande/Naturolyckor klimat/ oversvamning $/ \mathrm{V} \% \mathrm{C} 3 \%$ A4gledning $\% 20$ riskhanteringsplaner.pdf

OECD (Organisation for Economic Co-operation and Development). 2011. Water governance in OECD countries: a multilevel approach. OECD, Paris, France. http://dx.doi. org/10.1787/9789264119284-en

OECD (Organisation for Economic Co-operation and Development). 2014. Water governance in the Netherlands: fit for the future? OECD, Paris, France. http://dx.doi.org/10.1787/9789264102637en

Olsson, P., L. H. Gunderson, S. R. Carpenter, P. Ryan, L. Lebel, C. Folke, and C. S. Holling. 2006. Shooting the rapids: navigating transitions to adaptive governance of social-ecological systems. Ecology and Society 11(1):18. [online] URL: http://www. ecologyandsociety.org/vol11/iss1/art18/

Pahl-Wostl, C., J. Sendzimir, P. Jeffrey, J. Aerts, G. Berkamp, and K. Cross. 2007. Managing change toward adaptive water management through social learning. Ecology and Society 12 (2):30. [online] URL: http://www.ecologyandsociety.org/vol12/ iss $2 / \operatorname{art} 30 /$
Pitt, M. 2008. Learning lessons from the 2007 floods: an independent review by Sir Michael Pitt. Cabinet Office, London, UK. [online] URL: http://webarchive.nationalarchives.gov. uk/20100807034701/http:/archive.cabinetoffice.gov.uk/pittreview/ thepittreview/final report.html

Préfet coordonnateur de bassin Artois-Picardie. 2015. Plan de gestion des risques d'inondation 2016-2021: Bassin ArtoisPicardie, Districts de l'Escaut et de la Sambre. Préfecture de région Hauts-de-France, Lille, France. [online] URL: https://www. hauts-de-france.developpement-durable.gouv.fr/IMG/pdf/1-pgri artoispicardie-version-finale.pdf

Reed, M. S., A. C. Evely, G. Cundill, I. Fazey, J. Glass, A. Laing, J. Newig, B. Parrish, C. Prell, C. Raymond, and L. C. Stringer. 2010. What is social learning? Ecology and Society 15(4):r1. [online] URL: http://www.ecologyandsociety.org/vol15/iss4/ resp1/

Reimann, M., and R. Zimmermann. 2008. The Oxford handbook of comparative law. Oxford University Press, Oxford, UK. http:// dx.doi.org/10.1093/oxfordhb/9780199296064.001.0001

Söderasp, J. 2015. What about state implementation? New governance and the case of the European Union Water Framework Directive in Sweden. Europaräettslig Tidskrift 18 (3):508-524.

SPW (Service Public de Wallonie). 2015. District hydrographique international de l'Escaut: projet de plan de gestion des risques d'inondation en Wallonie 2015-2021. SPW, Jambes, Belgium. [online] URL: http://environnement.wallonie.be/inondations/ files/pgri/PGRI ESCAUT 20150424.pdf

Suykens, C. 2015. EU Water quantity management in international river basin districts: crystal clear? European Energy and Environmental Law Review 24(6):134-143.

Suykens, C., S. J. Priest, W. J. van Doorn-Hoekveld, T. Thuillier, and M. van Rijswick. 2016. Dealing with flood damages: will prevention, mitigation, and ex post compensation provide for a resilient triangle? Ecology and Society 21(4):1. http://dx.doi. org/10.5751/ES-08592-210401

Tennekes, J., P. J. P. Driessen, H. F. M. W. van Rijswick, and L. van Bree. 2014. Out of the comfort zone: institutional context and the scope for legitimate climate adaptation policy. Journal of Environmental Policy and Planning 16(2):241-259. http://dx.doi. org/10.1080/1523908X.2013.836961

Thorsteinsson, D., and R. Larsson. 2012. Översvämningsförordningens betydelse för fysisk planering/The impact of the EU Flood Directive on physical planning in Sweden. Journal of Water Management and Research 68:241-246.

van Buuren, A., P. Driessen, G. Teisman, and M. van Rijswick. 2014. Toward legitimate governance strategies for climate adaptation in the Netherlands, combining insights from a legal, planning, and network perspective. Regional Environmental Change 14(3):1021-1033. http://dx.doi.org/10.1007/s10113-013-0448-0

van Eerd, M. C. J., C. Dieperink, and M. A. Wiering. 2015. 'A dive into floods': exploring the Dutch implementation of the floods directive. Water Policy 17(2):187-207. http://dx.doi. org/10.2166/wp.2014.025 
van Kempen, J. J. H. 2012. Countering the obscurity of obligations in European environmental law: an analysis of Article 4 of the European Water Framework Directive. Journal of Environmental Law 24(3):499-533. http://dx.doi.org/10.1093/jel/ eqs 020

van Rijswick, M., H. K. Gilissen, and J. van Kempen. 2010. The need for international and regional transboundary cooperation in European river basin management as a result of new approaches in EC water law. ERA Forum 11(1):129-157. http:// dx.doi.org/10.1007/s12027-009-0145-0

van Rijswick, H. F. M. W., and H. J. M. Havekes. 2012. European and Dutch water law. Europa Law Publishing, Groningen, The Netherlands.

Walker, B., C. S. Holling, S. R. Carpenter, and A. Kinzig. 2004. Resilience, adaptability and transformability in social-ecological systems. Ecology and Society 9(2):5. [online] URL: http://www. ecologyandsociety.org/vo19/iss2/art5/

Wiering, M., C. Green, M. van Rijswick, S. Priest, and A. Keessen. 2015. The rationales of resilience in English and Dutch flood risk policies. Journal of Water and Climate Change 6(1):38-54. http:// dx.doi.org/10.2166/wcc.2014.017

Young, O. R., F. Berkhout, G. C. Gallopin, M. A. Janssen, E. Ostrom, and S. van der Leeuw. 2006. The globalization of socioecological systems: an agenda for scientific research. Global Environmental Change 16(3):304-316. http://dx.doi.org/10.1016/ j.gloenvcha.2006.03.004 